\title{
The Strange Story of Monk Ariyabalma*
}

Maurizio Riotto**

\section{Prologue}

The epic tale of ancient Korean monks who sought the Law of the Buddha in the West is sublime (sometimes tragic), and due to the scarcity of the remaining sources remains largely obscure. Sometimes they are unknown even to the ancient Korean chroniclers and their ethnicity is inferred from cross-comparisons between foreign sources, archaeological finds, and philological research. The case of Hyech'o 慧超 or 惠超 (ca. 700-ca. 780) ${ }^{1}$ is very significant in this regard. Completely neglected by ancient Korean sources, his name was discovered only by chance thanks

* This work was supported by Humanities Korea Plus Project through the Ministry of Education of the Republic of Korea and the National Research Foundation of Korea (NRF-2019S1A6A3A03058791).

** Anyang University, HK+ Project, lugalbanda@anyang.ac.kr

1 "Hyech'o" is obviously the religious name, after taking vows. It translates to the Sanskrit Prajñāvikrama प्रज्ञाविक्रम. Nothing is known of its secular name. The dates of birth and death are sometimes referred to as 704-787, but I have chosen a more prudent reference. On Hyech'o and his journey see, among others, Pang Sanghyŏn, "Hyech'o-ŭi chung'ang Asia Yŏkpanggo [Study on the visit to Central Asia of Hyech'o]," Kyŏnghŭi sahak 20 (February 1996):1-33, Pak Kisŏk, "Hyech'o Wang o Ch'ŏnch'ukkukchŏn-ŭi kihaeng munhakchŏk koch'al [A study on Wang o Ch'ŏnch'ukkuk-chŏn of Hyech'o as travel literature]," Kojŏn munhak-kwa kyoyuk 12 (August 2006):33-58. 
to his document regarding Far Eastern travel literature, which was found, albeit mutilated, in 1908 in Dunhuang 敦煌. ${ }^{2}$

However, Hyech'o has remained in history only for his travel diary adventures. As for the other monks, only the most famous who returned home found a place in Korean history, and often only after Koreans themselves tracked down their biographies in Chinese texts. Their lives were thus recorded in works such as the Samguk sagi 三國史記 (History of the Three Kingdoms, completed in 1145), ${ }^{3}$ the Haedong kosüng-jŏn 海 東高僧傳 (Lives of the eminent monks of Korea, completed in 1215), ${ }^{4}$

2 The work is the famous Wang o Ch'önch'ukkuk-chŏn 往五天竺國傳 (Diary of a Pilgrimage to the Five Regions of India) found by Paul Pelliot (1879-1945). The only Far Eastern account of 8th century India, it presented itself to the discoverer in a manuscript and headless paper-made document, whose compilation date must have been close to that of the original. Although the text was missing the beginning and the end, it was not difficult for Pelliot to identify it with that quoted by the Chinese monk Huilin 慧琳 (737-820) in the last of the hundred books of his Yiqiejing yinyi 一切經音義 (General Dictionary of the Terms Present in the <Buddhist> Scriptures). See Yiqiejing yinyi in T.54 n. 2018 where T. indicates, from now on, Takakusu Junjirō 高楠順次郎 et al. (eds.), Taishō shinshū daizōkyō 大正新修大藏經 (Buddhist canon: new compilation of the Taishō era $<1912-$ 1926>). 85 volumes. Issaikyō kankōkai, Tōkyō 1924-32. Huilin, however, speaks of a work divided into three books, whereas the text found by Pelliot, although mutilated, still gives the impression of being in one book. If so, then Dunhuang's text could be considered an epitome of the original work. See M. Riotto (ed.), Pellegrinaggio alle cinque regioni dell'India (Milano: O barra O edizioni, 2010), 64-65. See also Chŏng Suil (ed.), Hyech'o-ŭi Wangoch'ǒnch'ukkuk-chŏn [The Wang o ch'ónch'ukkuk-chŏn by Hyech'o] (Seoul: Hakkojae, 2006).

350 books, commissioned by King Injong 仁宗 (r. 1122-1146) of Koryŏ 高麗, written by Kim Pusik 金富軾 (1075-1151) and completed in 1145. 2 vols. (Seoul: Ǔryu munhwasa, 1986).

4 Haedong kosŭng-jŏn 海東高僧傳 (Lives of the eminent monks of Korea). 2 surviving books of an unknown number, estimated from five to ten. Written by Kakhun 覺訓 (? -ca. 1230), Completed in 1215. References are to T.50 n. 2065. Among the Korean editions see Chang Hwiok 章輝玉 (ed.), Haedong kosŭng-jŏn 海東高僧傳 (Lives of eminent Buddhist monks), Seoul, Minjoksa, 1991, and Yi 
and the Samguk yusa 三國遺事 (Memorabilia of the Three Kingdoms, completed around 1280). ${ }^{5}$ These represent only the classic tip of the iceberg: we have only the names or a little more of other monks, but we can well imagine that many of them have been completely forgotten, becoming nothing but dust and shadows over the centuries. ${ }^{6}$

This study deals with a lesser-known monk Ariyabalma 阿離耶跋摩, ${ }^{7}$ who is cited very briefly in a Chinese work which later became a primary source for Korean historians. Technically and stylistically, the passages that concern him are similar to those concerning other monks, but their

Pyŏngdo 李丙壽 (ed.), Haedong kosŭng-jŏn 海東高僧傳 (Lives of eminent monks of Korea), Seoul, Urryu munhwasa, 1975. In languages other than Korean see the work by P. Lee (ed.), Lives of Eminent Korean Monks. Cambridge, Massachussetts, Harvard University Press, 1969.

5 In five books, it was written by the Master of the Buddhism Iryŏn (1206-1289), nominated "National Preceptor" in 1283. For the historical/critical edition of the work, cf. M. Riotto (ed.), Samguk yusa - Memorie dei Tre regni, Roma, Carocci editore, 2019.

6 Y. Lou estimates that there were one hundred and seventeen monks who traveled between Korea and China, sometimes even going to India, between the early sixth and early tenth centuries. See Y. Lou, Buddhism (Leiden: Brill, Lam edition, 2015), 211. Of at least twenty of them no trace remains in Korean texts (at least those that have come down to us) and their names survive only in Chinese texts such as the Jingde chuandeng $l u$ 景德傳燈錄 (Annals of the Transmission of the Lamp of the Jingde era), where "lamp" obviously stands for "Dharma", and the Song Gaosengzhuan 宋高僧傳 (Lives of the Eminent Monks Compiled in the Song era). See Daoyuan 道原 (sometimes referred to as Daoyan 道彦), Jingde chuandeng lu, 30 books (Seoul: Tongguk University, 1987). The Song Gaoseng-zhuan is found in T.50 n. 2061.

7 Even today's "secondary" sources do not say much: among the very few in Korea, I will cite Sŏ Kilsu, "Koguryŏ- Koryŏ-ŭi nara irŭm (kungmyŏng) -e kwanhan yŏn'gu I [A Study on the Name of the Nation Koguryŏ-Koryŏ I]," Koguryŏ-Parhae yŏn'gu [高句麗渤海研究] 50 (November 2014):119-164, and Kye Mihyang, "Han'guk kodae-ŭi Ch'ŏnch'uk kubŏpsŭng yŏn'gu [A Study of the Monks of Ancient Korea Who Sought the Law in India]," Ph.D. dissertation, Seoul, Tongguk University, 2016, 145-148. 
contents confirm the suspicion that he was a very particular character and different from most of his fellow monks. Ariyabalma was more adventurous than others (if not by mistake) but was also one of the various Buddhist monks who came from Korea and tried to improve themselves and the world by studying abroad.

\section{The Sources}

The very little we know about Ariyabalma (or Arinabalma 阿離那跋 摩) basically comes from three sources: one is Chinese from the seventh century (written a few years after the passing of the monk), and two are Korean from the 13th century that draw more or less heavily from the Chinese biography. The Chinese work is the well-known Da Tang xiyu qiufa Gaoseng-zhuan 大唐西域求法高僧傳 (Lives of Eminent monks who sought the Buddhist Law in the West at the time of the Great Tang), ${ }^{8}$ written in two books by the Chinese Master Yijing 義淨 $(635-713)^{9}$ in

8 T.51, n. 2066. For the English edition see L. Lahiri (ed.), Chinese Monks in India: Biography of Eminent Monks Who Went to the Western World in Search of the Law During the Great T'ang Dynasty (New Delhi: Motilal Banarsidass, 2015). Among Korean editions see, among others, Yi Yongbŏm (ed.), Tae Tang sŏyŏk kubŏp kosüng-jŏn [Lives of Eminent Monks Who Sought the Law in the West at Time of the Great Tang] (Seoul: Tongguk University, 1980), and Kim Kyuhyŏn (ed.), Tae Tang sŏyŏk kubŏp kosŭng-jŏn [Lives of Eminent Monks Who Sought the Law in the West at the Time of the Great Tang] (Seoul: Kŭllobŏl k'ont'ench 'ŭ, 2013).

9 He was certainly not anyone. Very esteemed by three emperors (Empress Wu Zetian 武則天 [r. 690-705], Zhongzong 中宗 [r. 684 and 705-710] and Ruizong 睿宗 [r. 710.712]), he was himself the protagonist of a journey to the west (during who also faced some very dangerous situations), as well as a talented translator of sacred texts. His experience abroad is admirably narrated in his Nanhai jigui neifa zhuan 南海寄歸內法傳 [Report on Buddhism sent by the South Seas], in T.54 n. 2125. On Yijing and its epoch cf. T. Sen, "Yijing and the Buddhist Cosmopolis of the Seventh Century," in Texts and Transformations: Essays in Honor of the 75th Birthday of Victor H. Mair, ed. H.Saussy (Amherst, Cambria Press, 2018), 345-368, 
691 or thereabouts. The two books bring together the lives of fifty-six monks, both Chinese and foreign. The fourth biography of the first book concerns "Ariyabalma from Silla"10 and I include the original below:

阿離耶跋摩者, 新羅人也。以貞觀年中出長安, 之廣脇, 〈王城山 名〉。追求正教，親禮聖蹤。住那爛陀寺，多閑經論，抄寫衆 經。痛矣歸心，所期不契。出雞貴之東境，没龍泉之西裔。即於 此寺無常, 年七十餘矣。〈雞貴者, 梵云矩矩吒醫說羅。矩矩吒是 雞, 醫說羅是貴, 即高麗國也。相傳云彼國敬雞神而取尊, 故戴 翎羽而表飾矣。那爛陀有池, 名曰龍泉。西方喚高麗為矩矩吒醫 說羅也 $>^{11}$ 。

Aliyebamo was from Xinluo 新羅. ${ }^{12}$ During the Zhenguan era 貞觀 ${ }^{13}$ he left Guangxie 廣脇 (name of a mountain near the capital $),{ }^{14}$ near Chang'an 長安, in search of the right religion, and went personally to visit, on pilgrimage, the Holy Places. Finally

especially p. 356 ff. On his work as a translator, see, among others, J. Chen, “Another Look at Tang Zhongzong's (r. 684, 705-710) Preface to Yijing's (635-713) Translations: With a Special Reference to Its Date," Indo tetsugaku bukkyō-gaku kenkyū 11, no.3 (March 2004): 1-23.

10 In the index of the work, however, the name appears as Ananyebamo 阿難耶跋摩 (in modern Chinese pronunciation; Ananyabalma in modern Korean pronunciation).

11 The text is reported from: <https://zh.wikisource.org/wiki/\%E5\%A4\%A7\%E $5 \% 94 \% 90 \% \mathrm{E} 8 \%$ A5\%BF\%E5\%9F\%9F\%E6\%B1\%82\%E6\%B3\%95\%Е9\%AB\% 98\%E5\%83\%A7\%E5\%82\%B3/\%E5\%8D\%B7\%E4\%B8\%8A>.

12 These are the (current) Chinese pronunciations of the (current) Korean pronunciations of Ariyabalma and Silla.

13 It went from 627 to 649 and was the reigning period of the Tang emperor Taizong 太宗.

14 Yijing's note generally reports 王城小名, that is: “nickname of the imperial capital" instead of 王城山名, but I believe that the old emendatio in the text reported here may be preferable and therefore accepted. 
stopping in the temple of Nalantuo 那爛陀, ${ }^{15}$ there he deepened his knowledge by studying a large number of Sacred Scriptures and theological treatises, which he then copied. Sad to say, however, he was taken at some point by the desire to return, and was unable to follow through on his intentions. Coming from the far east of the noble chicken, he ended his days at that temple, in the far west of the dragon's source. He was seventy years old. (With reference to the expression "noble chicken", it translates the Sanskrit “jujuzha yishuoluo 矩矩吒醫說羅," 16 where “jujuzha” means "gallinaceous" and "yishuoluo" means "noble." This expression indicates the country of Gaoli" because, at least as the Indians say, in that country the chicken-god is very honored and the inhabitants use chicken feathers to adorn themselves. As for

15 This is also known as Nālandā नालन्दा. The temple stood about ten kilometers from Rājagrha राजगृह (in Chinese: Wangshecheng 王舍城, today Rajgir राजगीर) and was a Mahāvihāra महाविहार (large monastery/temple complex) and an authentic international university of Buddhist studies equipped with a splendid library. It was destroyed in 1193 in the course of a Muslim invasion. In following Yijing, Iryŏn confirms that Ariyabalma passed away at the age of seventy, a detail which however is not provided in Haedong kosŭng-jŏn.

16 This transliteration has very little to do with Sanskrit phonetics (we only think of the Hindi "kukkuti कुक्कुटी", where "yishuoluo" could refer to the pāli "Issara" via the Sanskrit "iśvara" ईश्वर), but it is also true that the pronunciation of Chinese in the seventh century must have been somewhat different from the present one. Nor is it excluded that in his transliteration Yijing used the so-called "half-leaf" method (半切法), where the pronunciations of two contiguous syllables are "halved" to form one.

17 In Korean this is Koryŏ, and it certainly cannot be the state created in the tenth century, given that Yijing died in 713. Koryŏ is therefore an abbreviated form of Koguryŏ, as it is often found in classical sources, both Chinese and Korean. I omit here the problem of the term Koryo as a possible official name used in place of Koguryŏ by the same rulers of that country starting from a certain period (however not precisely recognized), and, about this question, I refer to the already quoted article by Sŏ Kilsu (see supra, note 7), especially pp. 122-126. 
the source of the dragon, it forms a pond near the temple. In the West, therefore, Gaoli is called Jujuzha yishuoluo).

I will return later to the last controversial passage on Gaoli, where Yijing seems to mistake Silla for Koguryŏ by committing (at least apparently) an error that instead may not even be an error. ${ }^{18}$ The issue is not insignificant because it could also directly affect Ariyabalma's true "nationality."

The second source is the aforementioned Haedong kosüng-jŏn, attributed to the semi-known Kakhun 覺訓 (? -ca. 1230), a figure ignored by official historiography despite being credited with having been the abbot of the temple Yŏngt'ong 靈通, not far from the Koryŏ 高麗 capital Kaegyŏng 開京 (currently Kaesŏng 開城). Information about Kakhun is only reported in works by some scholars such as Yi Illo 李仁老 (11521220), ${ }^{19}$ Yi Kyubo 李奎報 (1168-1241), ${ }^{20}$ and Ch'oe Cha 崔滋 (11881260), ${ }^{21}$ who were his friends or acquaintances. For the rest, he almost certainly belonged to the Flower Garland School (Hwaŏm 華嚴 or Ava-

18 To confirm that what Yijing writes here is not a mistake, the Chinese Master says the same thing in a note in the Introduction to his Nanhai jigui neifa zhuan: ... 雞貴者 西方名高麗國 為俱俱吒緊說羅 $\ldots .$.

19 Yi talks about him in book II of the three that make up his P'ahan-jip 破閑集 (Collection of writings to "kill" time). This work was actually published by Yi Illo's son, Yi Sehwang 李世黃, in 1260, but, like Pohan-jip 補閑集, it is known above all from an edition of 1659, edited by Ŏm Chŏnggu 嚴鼎考 (1605-1670), after the disappearance of the original. Seoul, Asea munhwasa, 1972.

20 Tongguk Yi sangguk-chip 東國李相國集 (Collection of Writings by Minister Yi of the Kingdom of Korea), book XVI. This work, in 53 books, was published by Yi Kyubo's son, Yi Ham 李涵 (? -?), in 1241. In 1251, twelve other books were added to the forty-one original books, obtained by rearranging the author's notes. Seoul, Minjok munhwa ch'ujinhoe, 1985.

21 Pohan-jip 補閑集 (Collection of Writings to Pass Time), book III. This work, in three books, was completed in 1254. Like P'ahan-jip, it was reprinted by Ŏm Chŏnggu 嚴鼎考 (1605-1670) in 1659. Seoul, Pogosa 2012. 
tamsaka अवतंसक) $)^{22}$ and, in spite of his religious choices, he probably had a very open mind, cultivating life's pleasures. A good writer and erudite, he produced various writings, including a "Criticism of Poetry" (Sip'yŏng 詩評, now lost) which seems to have been highly appreciated by his contemporaries. Precisely from the hints of his acquaintances it is understood that he died around $1230 .{ }^{23}$

The Haedong kosŭng-jŏn was completed by royal order in 1215 and certainly, seventy years later, Iryŏn 一然 (1206-1289), the author of the Samguk yusa, used it as a source, while not sparing him harsh criticism. ${ }^{24}$ Immediately after, however, the work entered into almost total oblivion, only to re-emerge in a document reporting only the first two books around the beginning of the twentieth century. The document was then printed, published and also included in the Japanese Buddhist canon, in which it is today referred to as T.50 n. $2065 .^{25}$ The passage on Ariyabalma, in the second book, is as follows:

釋阿離耶跋摩。神智獨悟。形貌異倫。始自新羅入于中國。尋師 請益。無遠不參。瞰悡冥壑。凌臨諸天。非惟規範當時。亦欲陶 津來世。志切遊觀。不殫遊邀。遂求法於西竺。乃遐登於苞嶺。

22 This is deduced not only from the allusions of his acquaintances, but also from a passage from Koryŏsa 高麗史 (History of Koryŏ) book XVII, from which it is clear that ceremonies connected with the Hwaŏm School were quite frequent in the Yŏngt'ong temple. Koryŏsa is a historical work in 139 books, written by Chŏng Inji 鄭麟趾 (1396-1478) et al., Published in 1451. Seoul, Sinsŏwŏn, 1992.

23 On the possible date of death of Kakhun see O Kwanghyŏk 吳光焃, “Kakukun-no jakunen-ni tsuite [Apropos of the Year of Kakhun's Death]," Indo Bukkyōgaku kenkyū 28 (1979): 194-195.

24 This is unless the work cited by Iryŏn is not the homonymous (and now lost) work by Kim Taemun 金大問 (VII-VIII century), written half a millennium before and perhaps still in circulation in the thirteenth century. See in this regard Pak Yŏngho, "Haedong kosŭng-jŏn koch'al [A study on Haedong kosŭng-jŏn," Tongbang hanmunhak 4 (1988): 95-105 (96-97).

25 <http://tripitaka.cbeta.org/T50n2065_001> (book I) and <http://tripitaka.cbeta.or g/T50n2065_002> (book II). 
搜奇討勝。歷見聖蹤。夙願已圓。資糧時絕。乃止那爛陀寺未幾 終焉...

Reverend Ariyabalma had achieved Enlightenment alone, thanks to his wisdom and super-infused powers. His figure and appearance differed from those of every other person. When he went to China from Silla, looking for a teacher from whom he could learn, ${ }^{26}$ he did not refrain from going anywhere, however remote it might be. Thus, he traveled to the deepest valleys but also from there, after having rested a little, disdaining everything else he went back to Heaven. ${ }^{27}$ He wanted to set the rules of right behavior not only for his contemporaries, but also for future generations. Pursuing his will to travel and get to know the world, he never stopped traveling to distant places. In the perennial search for the Law, he eventually reached India, in the west, going up to the remote plateau of Ch'ongnyŏng 葱嶺. ${ }^{28}$ He made any possible effort in order to satisfy his pious desires. In the end, lacking the means of sustenance, he retired to the temple of Narant'a 那爛陀, ${ }^{29}$ where he died a short time later...

It seems that Kakhun did everything to distinguish and separate Ariyabalma from his fellow monks who were at different temples despite having made the journey in the same period. This is rather unusual when the company of one's compatriots was usually welcome, especially in an environment completely different from that of one's origin. Moreover,

26 A teacher who, apparently, he never had, if we must lend faith to what was stated in the previous sentence.

27 The passage is far from clear (凌臨諸天), but I like to read it in allegorical form, meaning the "deepest valleys" like that worldly life that ultimately provokes the disgust of the religious-men, urging at the same time their contemplative nature.

28 Chinese: Congling. This is the Pamir, which Hyech'o, in his pilgrimage to the five regions of India, calls P'amil 播密.

29 It is always the temple-complex of Nālandā, this time pronounced in Korean. 
Kakhun remains silent about the age of the monk at the moment of his death and makes no mention of a possible "cult of the chicken" present in Korea. However, he says that Ariyabalma came from Silla and adds some details not provided by Yijing (and it is not known from which other source), such as self-enlightenment and the withdrawal to Nālandā after the economic difficulties that have arisen. As for the fact that Ariyabalma is not with other monks, is it a question of incompatibility, of linguistic differences, or something else? We will return to this in the last part of the article but in the meantime let us move on to the third source with the passage dedicated to the monks who sought the Buddhist law in India as it is found in book IV of Samguk yusa: ${ }^{30}$

廣函求法高僧傳云 釋阿離那（一作耶）跋摩（一作郎）新羅人 也初希正敎 早入中華 思唓聖蹤 勇銳彌增 以貞觀年中 離長安 到五天 住那蘭陁寺 多閱律論 抄寫貝萊 痛矣歸心所期不遂 忽 於寺中無常 齡七十餘 ... 天竺人呼海東云 矩矩吒硻說羅 矩矩 吒 言雞也 䃜說羅 言貴也 彼土相傳云 其國敬雞神而取尊 故戴 翎羽而表飾也...

In the Kubŏp kosŭng-jŏn 求法高僧傳, ${ }^{31}$ preserved in the archive marked with the character "kwang 廣," we read as follows: “The monk Arinabalma 阿離那跋摩 32 (I prefer to write “ya 耶” instead of “na 那”. As for the final syllable “ma 摩”, it should perhaps be replaced by "rang 郎”) was from Silla. He soon went to China to look for the right religion, animated by the desire to follow in the footsteps of the saints. So, he reached Chang'an, the capital of Tang, and from there, during the Chonggwan era, he left for the five regions of India. He stopped at Narant'a 那蘭陁 temple,

30 The passage is taken from the imsin 壬申 text of 1512, reported in M. Riotto (ed.), Samguk yusa .., cit., 637-733.

31 It is always Yijing's work.

32 The following passage in parentheses is a note by Iryŏn himself. 
where he studied Yulchang 律藏 and Nonjang 論藏 ${ }^{33}$ extensively, and copied various parts of numerous works. Taken with strong nostalgia, he thought of returning to his homeland, but his hopes failed and he died suddenly in that same temple at the age of seventy"... To indicate the country of the East, Indians use the expression Kukut'a Yesŏlla 矩矩吒䃜說羅, where “Kukut'a” means "chicken" and "Yesŏlla" means "noble." This is because, at least as the Indians say among them, the inhabitants of the Eastern Country hold in high esteem and respect the chicken god and they use chicken feathers to adorn themselves...

Iryŏn follows Yijing almost slavishly, but he diverges from the Chinese master on some occasions: for example, like Kakhun, he "brings" Ariyabalma to China, where Yijing shows him already residing in the Chang'an area. He also says that those who indicate Korea (or Silla) as "Kukut'a Yesŏlla" are not the inhabitants of the western regions in general, but the Indians. Moreover, he specifies the nature of the texts examined by the Korean monk, but, above all, he replaces the term "Gaoli" (Koguryŏ) with the more general word "Haedong 海東," or "land east of the sea," where the "sea" is of course the Yellow Sea (but the character "hae 海” could also indicate the state of Parhae 渤海). It is a term that generally indicates the Korean peninsula, starting from its northern area, and it is not necessarily a synonym for Silla, even for foreigners. Remember, in this regard, how the wonderful letter that the Chinese master Fazang 法 藏 (643-712) wrote to the Korean monk Üisang 義湘 (625-702) around the end of the seventh century begins: ${ }^{34}$

33 Vinaya Pitaka विनयपिटक and Abhidharma Pitaka अभिधर्मपिटक. Note how Yijing says, more simply, "religious texts and treatises" (經論).

34 For more detailed studies on this document, see, among others, P. Lee, "Fa-Tsang and Uisang", Journal of the American Oriental Society, 82, no.1 (March 1962): 5662, and A. Forte, "Un gioiello della rete di Indra: la lettera che dalla Cina Fazang inviò a Ǔisang, in Corea", in Tang China and Beyond ed. A. Forte (Kyōto, Italian 
《西京崇福寺僧法藏 致書於海東新羅華嚴法師侍者》.

That is, “Fazang 法藏, monk from the Chongfu 崇福 temple in the western capital, writes this letter to Master Huayan's 華嚴35 attendant in the country of Xinluo 新羅, east of the sea."

"Xinluo" is the Chinese pronunciation of "Silla." If the "land east of the sea" had always indicated Silla, Fazang would not have had to specify (especially in an extremely concise language like Chinese) that Silla was there.

However, the use of the term "Haedong" in Iryŏn's text is probably a justified intervention, as we will see below. The following part will examine the peculiarities that emerge regarding the figure of Ariyabalma from the skimpy news concerning him.

\section{The Question of the Name}

In Korean historical texts one can find anonymous Korean Buddhist monks, monks recorded with both their secular name and Sino-Korean religious name, monks with their Sino-Korean religious name only, or even monks with both Sino-Korean and Indian religious names. As far as I know, Ariyabalma is the only Korean Buddhist monk of antiquity to have been recorded only by his Indian name. As we have seen, in fact, the three sources that concern him make no mention of it, nor could modern scholars, for this very reason, invent any of them. Yet there is no shortage of exceptions: in fact, the Sino-Korean name "Chullyun"36 (without char-

School of East Asian Studies, 1988), 35-83.

35 "Hwaŏm" according to the Korean pronunciation. It is always the School of the Flower Garland.

36 S.R. Tayal, India and The Republic of Korea: Engaged Democracies (London, New York, New Delhi: Routledge, 2014), 5. 
acters) or "Chollyun 尊輪”, 37 has been attributed to Ariyabalma. Such statements can only be explained if viewed as an attempt to do the reverse of what is normally done in these cases. The religious names of the Chinese and Korean Buddhist monks ${ }^{38}$ almost always translate concepts (and therefore terms) drawn from Sanskrit. In this way, knowing the SinoKorean name (and even in the absence of the Sanskrit term) one can somehow go back to its equivalent in Sanskrit since there are numerous cases (both in Chinese sources and in Korean sources) where the transliteration of the Sanskrit name is added to the Far Eastern name. For example, the Sino-Korean term "Hye 慧” usually corresponds to the Sanskrit "Prajñā प्रज्ञा," the term "Pŏp 法” to the Sanskrit "Dharma धर्म," etc.

The inverse operation (i.e. starting from Sanskrit to get to Sino-Korean) is certainly possible, but it is more hazardous, and not only because the writing of Sanskrit is alphabetic while the Sino-Korean is ideographic. Other obstacles are the richness and the phonetic/lexical diversity of Sanskrit itself, whose sounds do not correlate well to foreign languages, and the fact that in the absence of the Far Eastern name only the transliteration of the Sanskrit names in Chinese or Korean remain since it is usually only the Far Eastern sources to report them. Further, the transliteration is sometimes incorrect, misunderstood, or changes from author to author or even, as we have seen in the cases of Yijing and Iryŏn, it is reported in different forms within the same work.

In the case of Ariyabalma, thus, we have three different transliterations

37 J. Grayson, Korea: A Religious History (Oxford, Clarendon Press, 2002), 39 (I ed. 1989). A "Chollyun" as counterpart of Āryavarman is not even mentioned by Yi Nŭnghwa 李能和 in his work still fundamental for the study of Korean Buddhism, and therefore I really think it must be a completely arbitrary reconstruction. See Yi Nŭnghwa, Chosŏn Pulgyo t'ongsa [A Complete History of Korean Buddhism] 8 vols (Seoul, Tongguk University, 2010), vol. 3 p. 89 and vol. 4.1, p. 413. This work was first published in 1918.

38 I could say not only names but all the terms connected with Buddhism. Always valuable for the scholar, in this regard, is the work of W. E. Soothill and L. Hodous, A Dictionary of Chinese Buddhist Terms (London, Kegan Paul, 1937). 
of the same name:

Ananyabalma and Ariyabalma (Yijing); Ariyabalma (Kakhun); Arinabalma and Ariyabalma (Iryŏn).

"Ariyabalma" is reported by all three authors and is therefore the preferred one, albeit with due caution. Nevertheless, the second part of the name is identical with all the authors. Given that the sound "v" is missing in both Chinese and Korean, and taking into account other well-attested cases, there are good reasons to believe that "Palma" or "Balma" are transliterations of the Sanskrit "Varman वर्मन,," a term related to the idea of "protection," "defense", or "armor." As for "Ariya," it is less certain but it can be safely assumed that it is the transliteration of "Ārya आर्य," a term whose semantic sphere is linked to concepts such as "honor," "veneration," "holiness," "wisdom," etc. In this way, "Ariyabalma" could rightly be the transliteration of the Sanskrit name Āryavarman आर्यवर्मन,, with the rough meaning of "defender of sanctity" or "wise/honorable armor." It is a typical name used within kṣatriya क्षत्रिय, the caste of the Buddha, and it is a king's name, well attested to also in the Hindu context. As a matter of fact, it is not by chance that it is found as a royal name in the Ocean of the Streams of Stories (Kathāsaritsāgara कथासरित्सागर) ${ }^{39}$ by Somadeva सोमदेव (11th century).

However, there are also those who cite the Korean monk as Ānandavarman आनन्दवर्मन,, ${ }^{40}$ probably relying only on the transliteration "Ananyabalma" from the introduction of Yijing, but here we find ourselves in uncertain territory, especially if we give Ānanda the Buddhist meaning of "beatitude." Whatever is the case, we are very far from the "Chullyun" or "Chollyun" illustrated above.

Leaving "Chun" or "Chon" aside for now, it is certain that the "lyun

39 Kathāsaritsāgara, book XVIII. It seems that the work was composed between 1063 and 1081. See C.H. Tawney (ed.), Kathāsaritsāgara (Katha sarit sagara: Ocean of the Streams of Story), 2 vols., Calcutta, Baptist Mission Press, 1880 (vol. I) and 1884 (vol. II).

40 S. Jain (ed.), The India They Saw, vol. I. (New Delhi: Ocean Books, 2011), 355. 
(ryun)" of the final part of the name is the Korean phonetic value of the Chinese character 輪 (and in fact it is reported as this), which means "wheel" and is very common in Buddhist religious names. This character is equivalent to the Sanskrit "chakra चक्र" and in no case corresponds to "balma." On the contrary, the Sino-Korean character that best translates “Varman” is “kap/gap 甲,” which also means “armor” or “defense.” Even today, "armor" in Korean is "kabot 甲옷" (or 갑옷), a name formed by the Sino-Korean term "kap 甲” (defense) and the pure Korean "ot 옷” (dress), hence, "defense dress" and therefore "armor." And if it is true that the term Ārya could have the Sino-Korean meaning "chon 尊" in the sense of "honorable" or "venerable," 41 it is also true that even more frequently it is translated as "sŏng 聖," a term that indicates wisdom, sacredness and holiness. If ever then Āriyabalma had a Sino-Korean religious name corresponding in meaning to Sanskrit, it must have been “Chon'gap 尊甲” or “Sŏnggap 聖甲” and certainly not “Chullyun” or "Chollyun." 42

However, the question remains as to why the Sino-Korean religious name did not survive. It is very probable that Yijing and Ariyabalma got to know each other in person since the Chinese monk stayed in Nālandā for about ten years until 685. Ariyabalma, who had come from Chang'an and intellectually was certainly no fool, should also have known a mini-

41 See, for example, H. Chen, "The Encounter of Nestorian Christianity with Tantric Buddhism in Medieval China", in Hidden Treasures and Intercultural Encounters, ed. D. W. Winkler and Li Tang (Wien, LIT, 2009), 195-214 (203).

42 Yijing already points out the mistake in Hyeryun's 惠輪 biography, which is rendered almost identically by Kakhun in the second book of Haedong kosŭng-jŏn: 釋惠輪. 新羅人. 梵名般若跋摩 (唐云惠甲). That is: The master Hyeryun was from Silla and his Sanskrit name was Panyabalma (Hyegap in Chinese). "Panyabalma" is the transcription of "Prajñāvarman प्रज्ञावर्मन्" for which, in fact, "ryun" corresponds in this case to "varman." But this is a translation error, which in fact is pointed out by Yijing himself and also by modern critics, such as Chang Hwiok (cit., 214, note 268). Just this mistake, however, may have influenced some subsequent translations. 
mum of Chinese and this would have allowed the two monks to entertain some form of dialogue. If Yijing can afford to report the precise age of Ariyabalma's death (which is quite rare, especially for an otherwise unknown monk), it is probably because the Korean monk himself had provided him with some of his personal data. However, among these, there must also have been the Sino-Korean religious name, so then why does Yijing not report it, despite it being much easier for him to remember than the Indian name? And why is Yijing capable of reporting the Sino-Korean religious names of the monks of other monasteries but not that of Ariyabalma, who resided in his same monastery? If you do not want to think of Yijing's mnemonic slip, only two hypotheses remain. The first is that Ariyabalma, for certain reasons, did not intend to reveal his Sino-Korean religious name; the second is that Ariyabalma, the Sino-Korean religious name, never actually had it. But this will be discussed later.

\section{The Question of "Nationality"}

Reading Yijing's biographies, two things immediately catch the eye: the first is that all Korean monks appear as "Silla's." The second is a consequence of the first, because at the end of (Silla's) Ariyabalma's biography the author adds a long note in which he explains how and why the expression "noble chicken" (Jujuzha yishuoluo) was attributed to Gaoli, that is to $\mathrm{Ko}(\mathrm{gu})$ ryŏ. The contradiction is striking and it is difficult to think that a scholar of the caliber of Yijing could have been so grossly contradicted in just two lines. It is therefore necessary to understand why the Chinese Master expressed himself in this way.

The Chinese term rendered in Sanskrit as Jujuzha yishuoluo is Jigui 雞 貴 (Korean: Kyegwi) where ji means "chicken" and gui means "illustrious" and "noble." At this point, the first geographic expression that is associated with this term is Silla, due to the foundation myth which I report here from Book I of the Samguk yusa. After the miraculous birth from an egg of the future king Pak Hyŏkkŏse 朴赫居世, the first ruler of 
Silla, the text reports the following:

. . . 聖年至十三歲 以五鳳元年甲子 男立爲王 仍以女爲后 國 號徐羅伐 又徐伐（今俗訓京字云徐伐 以此故也）或云斯羅 又 斯盧初王生於鷄井 故或云鷄林國 以其鷄龍現瑞也一說脫解王 時得金閜智 而鷄鳴於林中 乃改國號爲鷄林 後世遂定新羅之號.

... When the two young royal children ${ }^{43}$ reached the age of thirteen, in the kapcha year, the first of the Obong 五鳳 $e r a,{ }^{44}$ the boy became king and the girl his queen. The country was called “Sorrabŏl 徐羅伐," but also “Sŏbŏl 徐伐," “Sara 斯羅” or “Saro 斯盧” (for this reason there is now the custom of calling the capital "Söbŏl"). Since the king was born at the spring of the hen, the country was also called "Kyerim 鷄林," or "hen/rooster forest." This is because the dragon-chicken had appeared there. Another version of the story says that the name "Kyerim" is due to the fact that when Kim Alchi 金閍智 45 came into the world during the reign of T'arhae 脫解, ${ }^{46}$ a hen/rooster crowed from the thick of a forest ${ }^{47}$ It was only after that, finally, that the name "Silla" was chosen.

43 They are Hyŏkkŏse and Ar'yŏng 䦓英.

44 Chinese: Wufeng. It indicates the fifth reigning period of Emperor Xuan 宣 (r. 74$49 \mathrm{BC}$ ), of the earlier Han 前漢, who went from 57 to $54 \mathrm{BC}$. The year in question is therefore $57 \mathrm{BC}$.

45 The descendants of this character would then have obtained the throne of Silla, first rulers of surname "Kim". An interesting legend, however, wants him to be a descendant of Kim Ilche 金日磾 (Chinese: Jin Ridi. Ca. 134-86 BC), a Xiongnu 匈奴 Prince, captured by the Chinese and made a slave first, who later bought great prestige among the Han.

46 The fourth ruler of Silla. According to tradition, he reigned from 57 to 80 .

47 More probably a rooster. The story is found in Samguk sagi, books I and XXXIV. The fact would have occurred in 65 . 
Silla is therefore called Kyerim and not Kyegwi. Not only that, but the term Kyerim seems unknown in the Chinese texts of the period and to have been circumscribed and used exclusively in the area of Silla for the use and consumption of its inhabitants. ${ }^{48}$ For this reason, the certainty of Ariyabalma's country of origin as "far east of the noble chicken" where Yijing meant "Silla" begins to falter and lose ground. Moreover, immediately afterwards the Chinese master clearly says that "Westerners" (which does not necessarily mean only the Indians, but also the Iranians and the Turkic peoples of Central Asia) call "noble chicken" Koguryŏ, and not Silla. Little is known about the uses of Koguryŏ and its folklore, including popular cults. It is certain, however, that the founding myth of this kingdom does not provide for the intervention of a chicken for any reason, unless Yijing alludes to the "three-legged crow" (samjogo 三足烏) that might have been popularized as "chicken" in the West. On the other hand, there is no evidence of a "chicken cult" in Silla; as a matter of fact, the only element that unites the myths of the two states is the birth of the founder from an egg.

Doubts also assail Iryŏn, who in reporting the Yijing's passage replaces "Kyegwi/Koryŏ" with "Haedong," thus providing a "diplomatically correct" generic expression, which avoids referring to one or all of the other old kingdoms of Korea. On the other hand, from the Samguk yusa itself it can sometimes be inferred that Haedong may refer to Koguryo ${ }^{49}$ and in

48 P. Lee (ed.), Lives of Eminent ..., cit., 85, note 431. The first attestation of the name Kyerim refers to 663, when Emperor Gaozong 高宗 renamed Silla as Kyerimju todokpu 鷄林州都督, that is to say, “Area Command of Kyerim Territory” and is found in Jiu Tang shu (Old History of Tang), 200 books. Compiled by Liu Xu 劉昫 (887-946), completed in 945. Beijing, Zhonghua shuju, 1975. See Jiu Tang $s h u$, book CIC. The term "kyerim" will then end even in the title of an interesting Chinese work from the very early 12th century, entitled Jilin leishi 鷄林類事 (Kyerim yusa, Various Facts of Kyerim, by Sun $\mathrm{Mu}$ 孫穆), which deals with Korean language and culture.

49 This is the case, for example, of the biography of Wŏngwang 圓光 in Book IV, where it is said that this master was of Chinan 辰韓 (i.e. Silla) and “continued the 
some cases the very name of Koguryŏ is applied to historical contexts that are absolutely unthinkable regarding chronology. ${ }^{50}$ It is a fact, however, that Yijing, in speaking of the "east of the noble chicken" unhesitatingly uses the term "Ko(gu)ryŏ," and since Yijing's only hint of Koguryŏ is found in Ariyabalma's biography, the possibility that the Korean monk was actually from Koguryŏ, (and not from Silla) becomes concrete and credible. ${ }^{51}$ But if so, why is the Korean monk presented as "Ariyabalma of Silla"? Here perhaps the solution is simpler. Ariyabalma was presumably born between 605 and 615 and left China during the Zhenguan era, that is, at the latest, in 649. Koguryŏ still existed in that year, but less than twenty years later the armies of the Silla-Tang coalition defeated Koguryŏ. From 668, of the old Korean kingdoms only Silla existed, and since Yijing completed his work around 690, he could only present each Korean monk as a "monk of Silla." Therefore, the fact that the note on Koguryŏ was only affixed to the biography of Ariyabalma suggests that the latter

tradition of his predecessors of Haedong” (家世海東祖習綿遠). Wōngwang was born around 550, that is, a few years after the official acceptance of Buddhism in Silla: what "predecessors" could he have had in this country? It is clear that, if you do not mean "Korean peninsula" in general, it is another country where Buddhism had previously established itself, probably Koguryŏ itself.

50 In book III of Samguk yusa, for example, it is said at some point that in the year 827 such a monk of Koguryŏ called Kudǒk 丘德, returned to Silla from China with some boxes full of Buddhist scriptures. This obviously is not possible, given that Koguryŏ, as a state, disappeared in 668. In this case, therefore, the term Koguryŏ almost certainly indicates Parhae 渤海, the state born from the ashes of Koguryŏ which survived until 926.

51 Indeed, the possibility that Ariyabalma was a native of Koguryŏ has already been hypothesized also by Sŏ Kilsu, "Koguryŏ- Koryŏ-ŭi nara irŭm (kungmyŏng) -e kwanhan yŏn'gu I," 144 ff. and, especially, 160: [Hence, it can be understood that the incorrect translation of "Kori" with "Silla" begins after the foundation of Koryŏ by Wang Kŏn. For this reason, Ariyabalma, protagonist of one of the biographies of Haedong kosŭng-jŏn, is recorded as a man of Silla once his birth in "Kyegwi" ("Kori") has been excluded. The same occurs in Samguk yusa, where the term "Kyegwi" is reported as "Haedong."] 
was actually originally from Koguryŏ, and Yijing wanted to somehow preserve his national identity, different from that of the other Korean monks, through his note.

\section{The Question of "Personality"}

The most controversial source, ${ }^{52}$ the Haedong kosŭng-jŏn, leads to many questions about Ariyabalma's personality, some details of which are not reported by Yijing, nor are followed by Iryŏn. As already mentioned, it is not known where Kakhun found such details, unless he just invented them. It is certain, however that his information, cross referenced with that of the other two sources, produces a rather particular portrait of the Korean monk.

Kakhun usually begins his biographies by describing the nationality and appearance of the character, but in the case of Ariyabalma he immediately opens with a "shocking" statement, about the monk achieving Enlightenment alone, and therefore not at the end of a guided spiritual path. Some might say that the hint of "self-Enlightenment" is a literary formula, used in connection with Buddhist saints, which indicates a high degree of perfection, and this is true. However, it is also true that Kakhun uses this expression only for Ariyabalma, and not even for other certainly more "famous" monks.

This is a condition that upset the classic structure of the biography, but which could be confirmed, in some way, in the biography compiled by Yijing. It is clear that the Chinese master is silent on Ariyabalma's "Korean" experiences and begins his story from when the latter is already in

52 We must not forget, in fact, that Haedong kosŭng-jŏn is suspected of being a forgery made by the monk Sasŏn 師玷 (or also Yusŏn 有玷) Yi Hoegwang 李晦光 (1862-1933) at the beginning of the twentieth century. On the question see M. Riotto, "On the question of the Authenticity of Haedong kosüng-jŏn," Rivista degli studi orientali XCIII, 1-2 (Dec 2020): 321-340. 
Chang'an, or rather, in a mountain near Chang'an. Being in a mountain does not necessarily mean residing in a temple (in fact Yijing does not talk about it) or having received the ordination as a monk. In this regard, one must imagine that even in those days there was a large number of people who, in following "self-enlightenment," cut their hair like monks, practiced asceticism and followed the precepts even without having taken vows. These people, who actually were laymen (sometimes even with wives and children), did not reside in temples, but in caves or other occasional shelters, perhaps built by themselves or even in their own homes. The Samguk yusa presents various examples and stories related to this particular type of lay devotees ${ }^{53}$ who have now become true muaein 無 导人 (Humans without impediment [in the soul]), which are often indicated by the term kosa 居士. ${ }^{54}$ Ariyabalma, at least at the beginning, could have been one of these, and therefore would have been devoid of the religious name taken after the pronouncement of vows.

Kakhun continues his story by mentioning the peculiar aspect of Ariyabalma (and this is not an exceptional thing, even if it still represents an element of differentiation from others) ${ }^{55}$ and the fact that from Silla he

53 See, for example, the story of Nojim Pudŭk 努朕夫得 and Taldal Pakpak 怛怛朴朴 in Samguk yusa, book III.

54 The term kŏsa is very frequent in Samguk yusa and in most of cases it may be translated as "lay devotee" or, in general, "one who practices self-reclusion or other types of actions typical to monks." In the Chosŏn Period, this term degenerates ending up indicating, in many cases, the members of namsadang 男寺黨 artistic groups, who often were the husbands of sadang 寺黨 women.

55 We do not know how Ariyabalma was aesthetically different from ordinary people. Medieval Western sources such as William of Rubruck's Itinerarium report that the Solanga were particularly dark-skinned: [Post Tebet sunt Solanga, quorum nuntios uidi in curia, qui adduxerant magnas bigas plus quam decem, quarum quelibet trahebatur sex bobus. Isti sunt parui homines et fusci sicut Hispani... (After the Tebet lie the Solanga, whose envoys I saw at court. They had brought more than ten large wagons, each of which was drawn by six oxen. They are small, with a dark complexion like the Spaniards...).] The Solanga have now been identified with the Koreans (the Mongols still call the Koreans "Solongos Солонгос"), now with a 
went to China in search of a teacher. Kakhun therefore assumes that Ariyabalma is from Silla, but this problem has already been discussed. Rather, it is surprising that one who has achieved Enlightenment on his own was looking for a master and in fact Kakhun does not say that Ariyabalma managed to find one, whereas he is meticulous in pointing out the mentors and tutors of other monks. But if Ariyabalma was looking for a teacher, perhaps he did not need a teacher of doctrine but, rather, a language teacher, and the language (given the interests of the monk) could only be Sanskrit. The confirmation could come from the fact that after searching far and wide he decided to go directly to India, where he presumably acquired the knowledge that would allow him to copy religious texts at Nālandā.

At this point we must consider the fact that Ariyabalma was probably from Koguryŏ, from where he may have moved after the coup of 642 by Yŏn Kaesomun 淵蓋蘇文 (? -665), the pro-Taoist dictator whose antiBuddhist policy had caused illustrious emigrations, like that of the master Podǒk 普德 mentioned in the Samguk yusa ${ }^{56}$ who had taken refuge in Paekche. In this regard, it cannot be excluded (indeed, it is quite probable) that Ariyabalma belonged (as often happened for religious who went abroad $^{57}$ to an illustrious pro-Buddhist family (if not even to the Royal family) of Koguryŏ and therefore in leaving the homeland he also had a political as well as a religious reason. Hence his prudence in meeting other monks and exposing himself at the level of personal data.

branch of the Malgal/Jurchen, now with the Suolun 索倫 (Evenki) of Chinese sources. In any case, we are always in the geographical context of Northern Korea/Manchuria to which Ariyabalma must have belonged, if really the latter was a man from Koguryŏ. On the whole question see M. Riotto: "Apropos of Solangi and Caule," Horizons: Seoul Journal of Humanities 6, no.2 (December 2015): 177-204.

56 Samguk yusa, book III. Podŏk left Koguryŏ in 650.

57 In fact, the laws on emigration/immigration existed even at the time and one can imagine how it was easier for members of certain categories and social classes to move from one country to another than for other ordinary citizens. 
It is also possible that Ariyabalma did not live entirely outside the secular world. The aforementioned passage of Haedong kosüng-jŏn where from the "deepest valleys" he "went back to heaven" could allude to activities carried out in the context of his religious vocation and perhaps not exactly in line with it. On the other hand, it does not seem that until old age he resided in some temple, and therefore he had to find something to live on in his numerous travels before stopping in Nālandā right after running out of resources. ${ }^{58}$ Moreover, insufficient travels funds was a problem common to all travelers of the time (including monks) and Yijing himself was forced, at least once, to send letters to China with which he asked for financial aid.

The problem of the funds could have proved fatal for Ariyabalma, after the collapse of Koguryŏ. In that situation, he found himself forced to enter a temple, and perhaps to take those vows (and that religious name) which he had not taken until then. ${ }^{59}$ This could be the reason why he is known only by an Indian name. The homesickness that suddenly gripped him (which is already highlighted by Yijing and which is not easily found in the lives of other monks) may have been linked precisely to the apprehension derived from the news of the disappearance of his homeland. The already advanced age and the lack of resources, however, would have forever prevented him from returning. At this point, all the elements that we have examined, starting from that statement according to which he obtained Enlightenment alone, or that he retired to a temple only after

58 Kakhun's text leaves no room for doubt: 資糧時絕, that is: “as time went by, he ran out of resources for the trip." The term charyang 資糧 in fact indicates precisely what is necessary for travel, but it also has a Sanskrit correspondent, in the context of Buddhism, which is Sambhāra सम्भार, that is, the requirements of merit and knowledge. Unless Kakhun alludes to some obscure facts concerning Ariyabalma, however, I prefer to understand the term as "travel resources."

59 Just from Yijing we know that Hyŏnyu 玄遊, another monk (of Koguryŏ, according to Kakhun), became a pupil of the Chinese master Sengzhen 僧哲 and took his vows in Śrī Lanka, after deciding not to return home (probably because it no longer existed). 
running out of money, causes doubt that Ariyabalma was not necessarily a "professional" monk (among other things, we have seen that Āryavarman is not a name linked exclusively to Buddhism), but rather a more or less practicing lay person who traveled the world for pleasure, work, or by simple religious vocation, and assumed an Indian name. He had probably had many opportunities to deal with the secular world and it was only at a mature age that he decided (perhaps forced by necessity) to take vows (if he really took them), keeping that exotic name with which he is known today, and canceling his original identity, perhaps precisely because of a not exactly adamantine or politically uncomfortable past. And this makes the hypothesis possible that he never had a religious name before his stay at Nālandā.

\section{Conclusions}

At the end of this paper, let us try to propose, as far as possible, a reconstruction of Ariyabalma's earthly adventure. He was born in Koguryŏ, in a year probably between 605 and 615 and in a period in which his homeland was very strong, to the point of inflicting in 612 a serious and decisive defeat to the immense army of Sui 隋 that had attempted an invasion of Koguryŏ. The economic and social consequences of this military disaster eventually contributed to the end of the Chinese dynasty itself in 618 .

Ariyabalma probably came from a high-ranking family (perhaps he was even a cadet of the Royal House) and received an education appropriate to his status. He certainly professed the Buddhist religion, but it is not said that he was a monk. At some point he went abroad: maybe it was his government that sent him, maybe it was his own decision, or maybe it was an escape after the 642 revolution that had led to the assassination of the monarch of Koguryŏ. He reached Chang'an, the western capital of the Tang dynasty that had replaced the Sui in China, where it seems that he led a secluded life, perhaps because he took vows and entered a temple or 
perhaps because he, as a lay, withdrew into a hermitage both to cultivate the spirit and to conceal his identity after the political turmoil in his homeland.

On an unknown date (but no later than 649) he left Chang'an and travelled to the West, perhaps out of a religious vocation, perhaps out of simple desire for knowledge, or perhaps because his nationality and status had become a danger to himself. He observed the costumes, admired the landscapes, and started learning different languages. In those remote places nobody recognized him and he could also mix with the "dust of the world,", even to earn some money. In the meantime, he began to age and to have less and less financial resources. In Koguryŏ things went badly, and China has more than ever become an enemy. Even his supporters at Chang'an were no longer able to help him. In the end he is left without means of support and then decides to reach Nālandā, where perhaps he finally took his vows by finding at least a place to live and a cassock under which to enjoy a certain immunity and anonymity in the midst of hundreds of monks. Thus, he became Ariyabalma, with a king's name, and rewarded the temple for his presence by carrying out the activity of copyist (but not a translator: perhaps his language skills would not have allowed him). ${ }^{60}$ We do not know if the news of the fall of Koguryŏ reached him before or after entering Nālandā but in any case it represented a terrible blow to him, generating in his soul the natural concern for all the people he had once loved. Perhaps he still had time to meet Yijing and express to him his homesickness before his death.

Who knows if things really went like this. If what has been said about Ariyabalma's name and nationality can be considered "possible" the reconstruction of his personality shown here is absolutely hypothetical, since there are too few elements to investigate. Whatever is the story of Ariyabalma, with all its secrets it is just one of many linked to that unre-

60 This could be an additional element in support of the hypothesis that Ariyabalma had not decided from a young age to become an exegete and translator of sacred texts. 
peatable period that saw hundreds of people moving from east to west for cultural reasons, a phenomenon that would no longer have occurred until the contemporary age. And it is a phenomenon that still has many aspects to investigate and, if possible, to discover.

\section{References}

Primary sources

1. Da Tang xiyu qiufa gaoseng zhuan 大唐西域求法高僧傳 (Lives of eminent monks who sought the Law in the West at the time of the Great Tang). Written by Yijing 義淨 (635-713) around 690. References are to T. 51, n. 2066.

2. Haedong kosŭng-jŏn 海東高僧傳 (Lives of the eminent monks of Korea). 2 surviving books of an unknown number estimated from five to ten. Written by Kakhun 覺訓 (?-1230?), completed in 1215. References are to T.50 nr. 2065. On-line text: http://tripitaka.cbet a.org/T50n2065_001 (book I: retrieved December 10, 2020) and http://tripitaka.cbeta.org/T50n2065_002 (book II: retrieved December 10, 2020).

3. Jilin Leishi 鷄林類事 (Various Facts of Jilin [Kyerim]). Written by Sun $\mathrm{Mu}$ 孫穆, completed after 1103. Originally in three books, it survives in fragments reported by Chinese texts such as Suofu 說郛 (Discourses of the suburbs), first compiled in 1361 but known through successive editions, and Gujin tushu jicheng 古今圖書集成 (Complete collection of ancient and modern writings and illustrations), first printed in 1726. Seoul: Hanyang University pusŏl kukhak yŏn'guso, 1974.

4. Jingde chuandeng lu 景德傳燈錄 (Annals of the Transmission of the Lamp of the Jingde era). 30 books, Written by Daoyuan 道原 (sometimes reported as Daoyan 道彦) upon an imperial order issued in 1004, first of the Jingde era (1004-1007). Seoul: Tongguk Univer- 
sity, 1987.

5. Jiu Tang shu 舊唐書 (Old History of Tang). Also said just Tang shu 唐書. 200 books. Compiled by Liu Xu 劉昫 (887-946), completed in 945. Beijing: Zhonghua shuju, 1975.

6. Koryŏsa 高麗史 (History of Koryŏ). 139 books. Written by Chŏng Inji 鄭麟趾 (1396-1478) et al., published in 1451. Seoul: Sinsŏwŏn, 1992.

7. Nanhai jigui neifa zhuan 南海寄歸內法傳 (Report on Buddhism sent by the South Seas). 40 books. Written by Yijing 義淨 (635-713), completed around 690. References are to T.54, n. 2125.

8. P'ahan-jip 破閑集 (Collection of writings to "kill" time). 3 books. Written by Yi Illo 李仁老 (1152-1220). This work was actually published by Yi Illo's son Yi Sehwang 李世黃 in 1260, but, like Pohanjip 補閑集, it is known above all from an edition of 1659, edited by Ŏm Chŏnggu 嚴鼎考 (1605-1670), after the disappearance of the original text. Seoul: Asea munhwasa, 1972.

9. Pohan-jip 補閑集 (Collection of Writings to Pass Time). 3 books. Written by Ch'oe Cha 崔滋 (1188-1260), completed in 1254. Like $P^{\prime}$ ahan-jip, it was reprinted by Ŏm Chŏnggu 嚴鼎考 (1605-1670) in 1659. Seoul: Pogosa, 2012.

10. Samguk sagi 三國史記 (Chronicles of the Three Kingdoms). 50 books. Commissioned by King Injong 仁宗 (r. 1122-1146) of Koryŏ 高麗, written by Kim Pusik 金富軾 (1075-1151) and completed in 1145. 2 vols. Seoul: Ǔryu munhwasa, 1986.

11. Samguk yusa 三國遺事 (Memorabilia of the Three Kingdoms). 5 books. Written by Iryŏn 一然 (1206-1289), completed around 1280. Seoul: Ǔryu munhwasa, 1992.

12. Song Gaoseng-zhuan 宋高僧傳 (Lives of the Eminent Monks Compiled in the Song era). 30 books. Written by Zanning 贊寧 (9191001) and Zhilun 智輪, completed in 988. References are to T.50 n. 2061.

13. Taishō shinshū daizōkyō 大正新修大藏經 (Buddhist canon: new 
compilation of the Taishō era <1912-1926>). 85 volumes. Compiled under the direction of Takakusu Junjirō 高楠順次郎, Watanabe Kaigyoku 渡邊海旭 and Ono Gemmyō 小野玄妙. Tōkyō, Issaikyō kankōkai, 1924-32. To this work must be added 12 volumes of illustrations (zuzō 圖像) published by the Daizō shuppan of Tōkyō in 1933-34 and an appendix in three separate volumes (bekkan 別卷) published as Shōwa hōbō somokuroku 昭和法寶總目錄 (General Index of the treasures of the Law of the Shōwa era <1926-1989>) published between 1929 and 1934 by Issaikyō kankōkai and Daizō shuppan.

14. Tongguk Yi sangguk-chip 東國李相國集 (Collection of Writings by Minister $\mathrm{Yi}$ of the Kingdom of Korea). 53 books. Written by Yi Kyubo 李奎報 (1168-1241), this work was published by his son, Yi Ham 李涵, in 1241. In 1251, twelve other books were added to the forty-one original books, obtained by rearranging the author's notes. Seoul, Minjok munhwa ch'ujinhoe, 1985.

15. Yiqiejing yinyi 一切經音義 (General Dictionary of the Terms Present in the Scriptures). 100 books. Written by Huilin 慧琳 (737-820), completed around 810. References are to T.54 n. 2018.

\section{Secondary sources}

16. Chang, Hwiok (ed.), Haedong kosŭng-jŏn [Lives of eminent Buddhist monks]. Seoul: Minjoksa, 1991.

17. Chen, Huaiyu. "The Encounter of Nestorian Christianity with Tantric Buddhism in Medieval China." in Hidden Treasures and Intercultural Encounters. Edited by Dietmar W. Winkler and Li Tang. Wien: LIT, 2009, 195-214.

18. Chen, Jinhua. “Another Look at Tang Zhongzong's (r. 684, 705-710) Preface to Yijing's (635-713) Translations: With a Special Reference to Its Date." Indo tetsugaku bukkyō-gaku kenkyū 11, no.3 (2004): 123. 
19. Chŏng, Suil. (ed.) Hyech'o-ŭi Wangoch'ŏnch'ukkukchŏn [The Wang o ch'ónch'ukkuk-chŏn by Hyech'o]. Seoul: Hakkojae, 2006.

20. Forte, Antonino. "Un gioiello della rete di Indra: la lettera che dalla Cina Fazang inviò a Ǔisang, in Corea." in Tang China and Beyond. Edited by Antonino Forte. Kyōto: Italian School of East Asian Studies, 1988, 35-83.

21. Grayson, James H. Korea: A Religious History. ( $1^{\text {st }}$ edition 1989) Oxford, Clarendon Press, 2002.

22. Jain, Sandhya. (ed.) The India They Saw, vol. I. New Delhi: Ocean Books, 2011.

23. Kim, Kyuhyŏn. (ed.) Tae Tang sŏyŏk kubŏp kosŭng-jŏn [Lives of Eminent Monks Who Sought the Law in the West at the Time of the Great Tang]. Seoul: Kŭllobŏl k'ont'ench'ŭ, 2013.

24. Kye, Mihyang. Han'guk kodae-ŭi Ch'ǒnch'uk kubŏpsŭng yŏn'gu. [A Study of the Monks of Ancient Korea Who Sought the Law in India]. Ph.D. Dissertation, Seoul: Tongguk University, 2016.

25. Lahiri, Latika. (ed.) Chinese Monks in India: Biography of Eminent Monks Who Went to the Western World in Search of the Law During the Great T'ang Dynasty. New Delhi: Motilal Banarsidass, 2015.

26. Lee, Peter H. "Fa-Tsang and Uisang." Journal of the American Oriental Society 82, no.1 (1962): 56-62.

27. Lee, Peter H. (ed.) Lives of Eminent Korean Monks. Cambridge, Massachussetts: Harvard University Press, 1969.

28. Lou, Yulie. Buddhism. Leiden: Brill, Lam edition, 2015.

29. O, Kwanghyŏk. "Kakukun-no jakunen-ni tsuite [Apropos of the year of Kakhun's death]." Indo Bukkyōgaku kenkyū 28 (1979): 194-195.

30. Pak, Kisŏk. "Hyech'o Wang o Ch'ŏnch'ukkukchŏn-ŭi kihaeng munhakchŏk koch'al [A study on Wang o Ch'önch'ukkuk-chŏn of Hyech'o as travel literature]." Kojŏn munhak-kwa kyoyuk 12 (August 2006): 33-58.

31. Pak, Yŏngho. "Haedong kosŭng-jŏn koch'al [A study on Haedong kosŭng-jŏn]." Tongbang hanmunhak 4 (1988): 95-105. 
32. Pang, Sanghyŏn. "Hyech'o-ŭi chung'ang Asia Yŏkpanggo [Study on the visit to Central Asia of Hyech'o]." Kyŏnghŭi sahak 20 (February 1996): 1-33.

33. Riotto, Maurizio. (ed.) Pellegrinaggio alle cinque regioni dell'India. Milano: O barra O edizioni, 2010.

34. Riotto, Maurizio. "Apropos of Solangi and Caule." Horizons: Seoul Journal of Humanities 6, no.2 (December 2015): 177-204.

35. Riotto, Maurizio. Storia della Corea dalle origini ai giorni nostri. Milano: Bompiani editore, 2018 (1st edition 2005).

36. Riotto, Maurizio. (ed.) Samguk yusa. Memorie dei Tre regni. Roma: Carocci editore, 2019.

37. Riotto, Maurizio. "On the question of the Authenticity of Haedong kosŭng-jŏn." Rivista degli studi orientali, XCIII 1-2 (2020): 321-340.

38. Sen, Tansen. "Yijing and the Buddhist Cosmopolis of the Seventh Century." in Texts and Transformations: Essays in Honor of the $75^{\text {th }}$ Birthday of Victor H. Mair. Edited by Haun Saussy. Amherst: Cambria Press, 2018, 345-368.

39. Sŏ, Kilsu. "Koguryŏ - Koryŏ-ŭi nara irŭm (kungmyŏng)-e kwanhan yŏn'gu I [A Study on the name of the nation Koguryŏ-Koryŏ I]." Koguryŏ-Parhae yŏn'gu 50 (November 2014): 119-164.

40. Soothill, William E. and Hodous, Lewis 1937: A Dictionary of Chinese Buddhist Terms. London, Kegan Paul, 1937.

41. Tawney, Charles H. (ed.) Kathāsaritsāgara (Ocean of the Streams of Story). 2 vols. Calcutta: Baptist Mission Press, 1880 (vol. I) and 1884 (vol. II).

42. Tayal, Skand R. India and The Republic of Korea: Engaged Democracies. London, New York and New Delhi: Routledge, 2014.

43. William of Rubruck. Guglielmo di Rubruk: Viaggio in Mongolia, a cura di Paolo Chiesa. Milano: Mondadori, 2011.

44. Yi, Nŭnghwa. Chosŏn Pulgyo t'ongsa [A complete history of Korean Buddhism]. 8 vols. Seoul: Tongguk University, 2010. (First published in 1918.) 
45. Yi, Pyŏngdo. (ed.) Haedong kosŭng-jŏn (Lives of eminent monks of Korea). Seoul: Üryu munhwasa, 1975.

46. Yi, Yongbŏm. (ed.) Tae Tang sŏyŏk kubŏp kosŭng-jŏn (Lives of Eminent Monks Who Sought the Law in the West at Time of the Great Tang). Seoul: Tongguk University, 1980. 
<ABSTRACT>

\section{The Strange Story of Monk Ariyabalma}

This article deals with the life of a $7^{\text {th }}$ century Korean monk, briefly recorded in Da Tang xiyu qiufa Gaoseng-zhuan by Yijing, who perhaps met him personally at the Nālandā Monastery between 675 and 685. Later this Korean monk, known by the "Indianized" name "Ariyabalma," was also mentioned in Haedong Kosŭng-jŏn and in Samguk yusa. By comparing the three short biographies reported in these texts, this article reconstructs as far as possible Ariyabalma's original religious name, nationality and personality, three aspects of this figure almost never explored by scholarship. In the end, the main hypotheses put forward are that Aryabalma was from Koguryŏ and he may even have taken the vows very late, perhaps just at the time of settling in the Nālandā monastery.

Keywords: Ariyabalma, Āryavarman, Korean Buddhism, Korean monks in Chinese Texts, Korean Monks in India 
〈국문초록〉

\section{승려 아리야발마에 관한 고찰}

Maurizio Riotto (안양대학교)

이 논문은 의정(義淨)의 大唐西域求法高僧傳에서 나타난 7 세기 한국 승려 아리야 발마의 생애를 다룬다. 이와 관련하여 두 승려가 675년에서 685년 사이에 인도의 나란 타 (Nālandā) 수도원에서 개인적으로 만났을 가능성이 있다. 그 후에 아리야발마는 해 동고승전과 삼국유사에서도 기록된다. 이 세 가지 텍스트들에서 실어 있었던 짧은 전 기를 비교함으로써 이 논문은 아리야발마란 인물의 지금까지 탐구하지 않은 세 가지 측면을 (法名, “국적” 및 인격) 최대한 재구성해 본다. 결국, 제시된 주요 가설은 아리 야발마가 고구려 출신이며 아마도 나란타 수도원에 정착했을 때에만 승려의 계 (ordination)를 받았을 수도 있다는 것이다.

주제어: 아리야발마, 한국 불교, 중국 문헌의 한국 승려들, 인도의 한국 승려들 
